\title{
Subnival Processes and Subnival Sedimentation Mechanisms, the Pamir-Alay Mts., Tajikistan
}

\author{
Paweł Kroh *(D), Piotr Dolnicki (D) and Adam Łajczak \\ Institute of Geography, Pedagogical University of Krakow, ul. Podchorazych 2, 30-084 Kraków, Poland; \\ piotr.dolnicki@up.krakow.pl (P.D.); adam.lajczak@up.krakow.pl (A.Ł.) \\ * Correspondence: pawel.kroh@up.krakow.pl
}

Citation: Kroh, P.; Dolnicki, P.; Łajczak, A. Subnival Processes and Subnival Sedimentation Mechanisms, the Pamir-Alay Mts., Tajikistan. Land 2021, 10, 104. https://doi.org/ 10.3390/land10020104

Academic Editor: Enrique Serrano Cañadas

Received: 3 December 2020

Accepted: 20 January 2021

Published: 22 January 202

Publisher's Note: MDPI stays neutral with regard to jurisdictional claims in published maps and institutional affiliations.

Copyright: (C) 2021 by the authors Licensee MDPI, Basel, Switzerland. This article is an open access article distributed under the terms and conditions of the Creative Commons Attribution (CC BY) license (https:// creativecommons.org/licenses/by/ $4.0 /)$.

\begin{abstract}
Geomorphological research in the Fann Mountains of the Pamir-Alay has indicated that subnival processes are occurring. Contemporary subnival sediments indicate that complex relationships occur between the snow patches, subnival waters, and ground. Underneath a semi-permanent snow patch, snow melts slowly from the direction of the ground, resulting in a hollow that is filled with sediments produced by wash-down from the river terraces. The energy of subnival waters washes away and displaces sediments present underneath the snow patch, but also causes them to be redeposited. The sediment features imply a significant impact of the relief under the snow patch on the thickness of nival deposits and the nivation mechanism. The sediments also indicate that subnival waters may be under hydrostatic pressure, which has a considerable impact on both the snowmelt and sedimentation processes.
\end{abstract}

Keywords: subnival processes; semi-permanent snow patch; periglacial geomorphology; Pamiro-Alay Mts

\section{Introduction}

Pronival ramparts and other forms associated with nivation have been described in various parts of the globe, for example, [1-4] and others. Nival and glacial forms as well as their relations have been discussed for several decades, both in the field of terminology and of distinguishing the genesis mechanisms of forms, for example, [1,5-10]. Although the occurrence of snow patches and nival processes, nowadays, is highly variable in time and space, for example [11,12], the manifestations of nivation can be treated as a geoindicator of environmental conditions in mountains with different climates [13-16]. An overview of the terminology by Hedding [17] indicates a very wide variety of terms, not just names, but also landform differentiations. The variety of these forms is also evidenced by the large range of criteria used for the delineation of these forms, defined by Shakesby [18] and subsequently discussed by Hedding and Sumner [19] and Hedding [20]. The formation of pronival ramparts has been defined, for example [3,4,21], and the genesis of such forms has been described $[2,9,22]$, together with the forming and functioning of nival niches [23-28] and nival slopes [12,29]. In addition, snow-push mechanisms near snow patches have been recognized [30].

Knowledge about subnival processes is still very limited. The occurrence of solifluction has been observed both under snow patches and in their surroundings [31], as was the subnival transport of fine material [23,31]. The movement of boulders over subnival boulder pavement [32] has also been observed. Shakesby et al. [33] suggested an important role of subnival debris flows in the creation of pronival ramparts. Other processes identified by these researchers include subnival solifluction, water transport, as well as snow slides generating large shear stresses at their bases. As inferred from the above data, all types of subnival processes are highly dependent on local factors, such as the structure of the soils, the thickness and surface extension of the snow patch, and the way it melts. In addition to drawing attention to subnival processes, researchers have noted that semi-permanent 
snow patches protect the underlying ground from freeze-thaw cycles, frost shattering, and debris falls [12,34].

This paper aims to present observations about subnival mechanisms of sedimentation which have not been previously described. On the basis of the field observation and characteristics identified in the sediments outcrop, the subnival mechanisms of sedimentation are deduced. These observations indicate the complex relationships within a snow patch and its floor, including subnival water flow, melting of snow patch, and material movement on hydration conditions under the snow.

\section{Study Area}

The studies were carried out in Tajikistan, in the Pamiro-Alay Mts. (Figure 1), Central Asia. It forms part of the catchment area of the Aral Sea [35], and is, together with the Pamir Mountains, a region that supplies the Zeravshan River [36], a tributary of the Syr Darya River. The study area is located in the valley of Sarytag in the Fann Mountains. The elevation of the research area ranges between 2400 and 2435 m.a.s.l. It is characterized by a typical mountainous terrain, with steep slopes and active morphogenetic processes [37]. The section of the valley studied extends from west to east. This section has a fluvial nature, and the valley bottom is filled with fluvial and fluvio-glacial sediments. There are four distinct levels of terraces, identified as the "20" and " 15 " m levels occupying a major part of the valley bottom. The region is tectonically active [38]. The nearest weather station is located at Iskanderkul Lake (2204 m.a.s.l., Figure 2), where precipitation amounts to $271 \mathrm{~mm}$ /year and the average annual temperature is $6.6{ }^{\circ} \mathrm{C}$ [39]. Stations at higher elevations, i.e., Shahristan Pass (3143 m.a.s.l.) and Anzob Pass (3373 m.a.s.1.), have recorded $0.7^{\circ} \mathrm{C}$ and $-1.9^{\circ} \mathrm{C}$, respectively. During recent decades, an increase in temperature, a decrease in precipitation, and the occurrence of droughts have been noted in this region $[40,41]$.

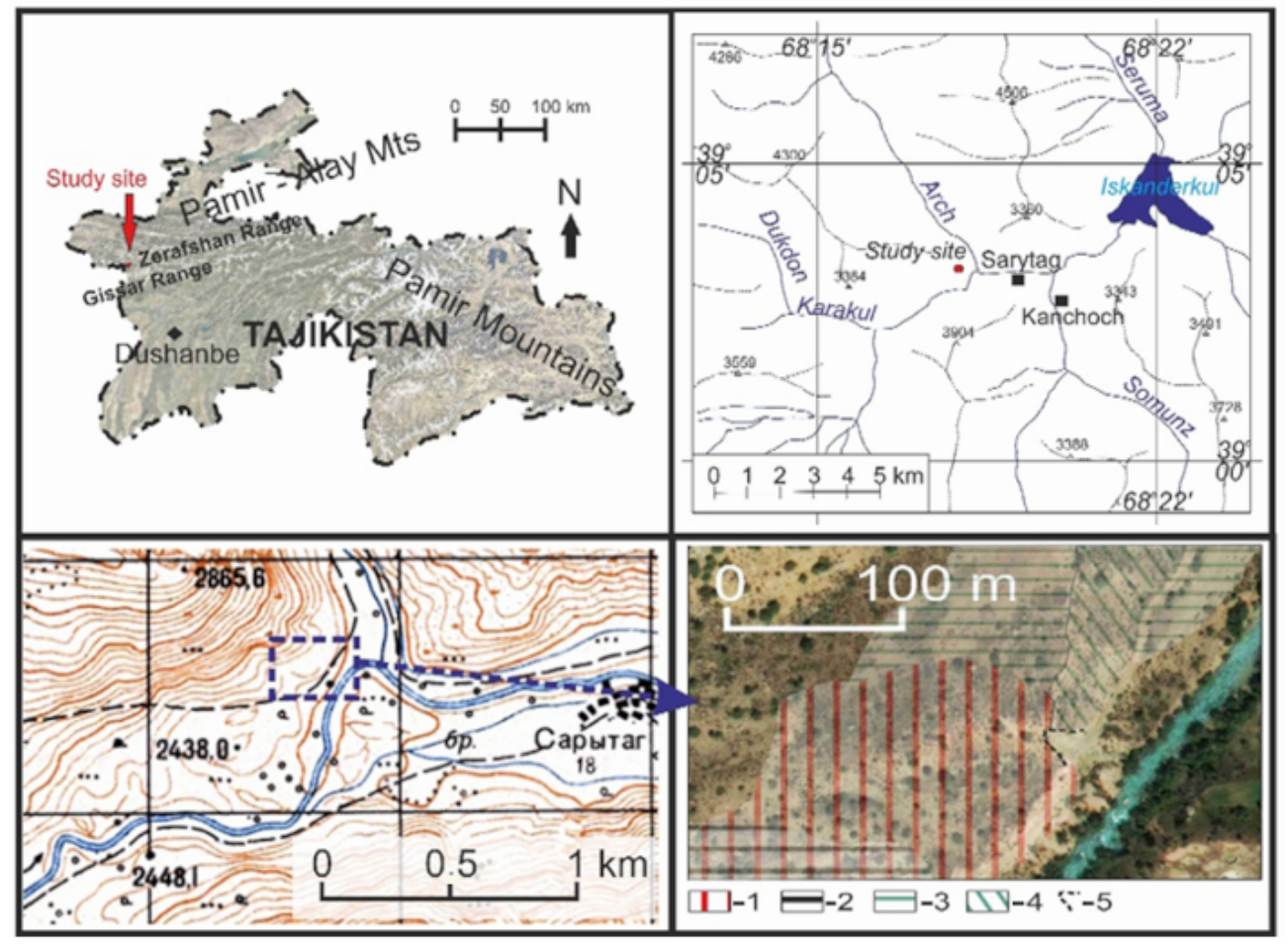

Figure 1. Study site location. 1, nival deposits; 2, rock fall deposits, 3, fluvial terraces; 4, slope between terraces; 5 , landslide scarp/study site. Topographic map by Military Survey of Soviet Union, orthophotomap by Google Earth Pro. 


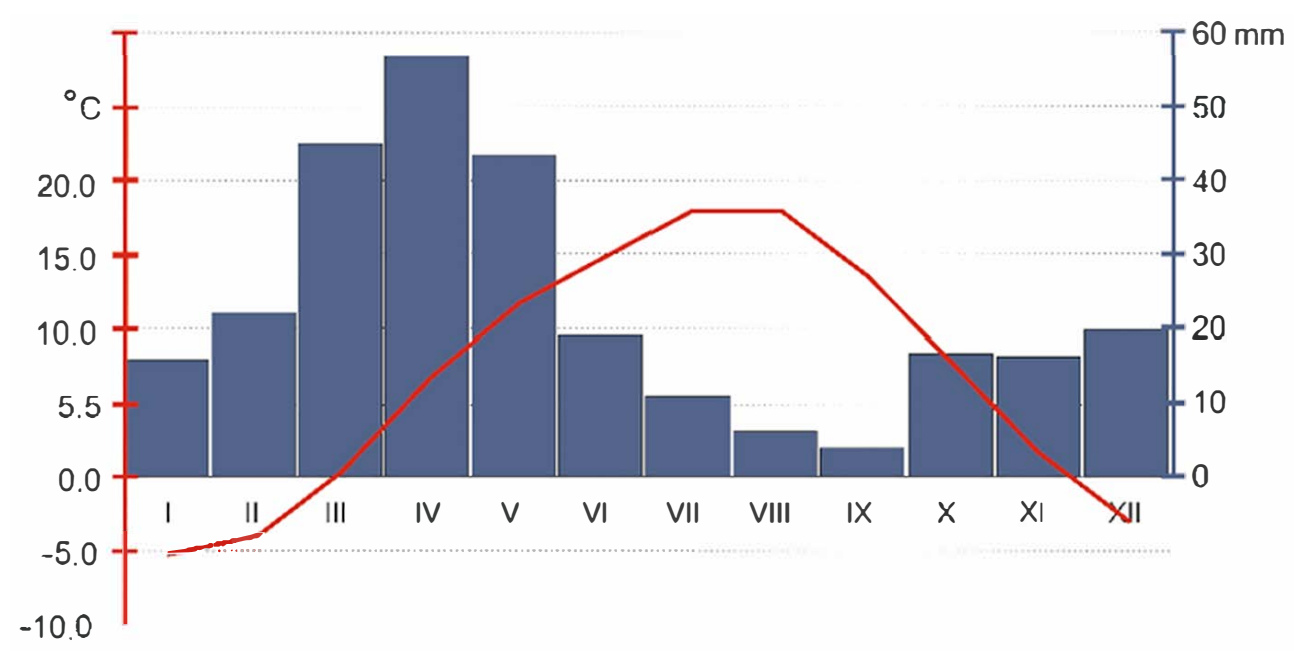

Figure 2. Climate chart for Iskanderkul station (source of data [39]).

The terminal moraines with the lowest position in the higher valley areas have been located at 2503 m.a.s.l., at a distance of approximately $3.5 \mathrm{~km}$ from the research area. The maximum extension of glaciation in the main part of the studied valley, dated at approximately $55 \mathrm{ka}$, reache 2780 m.a.s.l. [42] and its distance from the study area is $5.5 \mathrm{~km}$. The age of the youngest moraines, mapped at an elevation of 3020 m.a.s.l., is dated at between 19.6 and $21.6 \mathrm{ka}$ [42]. The vegetation in this area is typical of the high-mountain dry zone. At the altitude where the research was conducted, there are subalpine meadows and Juniperus sp. forests [43], which are subject to strong human pressure [37]. The western area of the Pamiro-Alay, including the Fann Mountains, is characterized by a great richness and diversity of flora, including the presence of a number of endemic species [44].

The study site is located in Sarytag Valley, just above its junction with Arch Valley. The Fann Mountains feature a fold structure. The valley section in which the nival deposits are found is built of sedimentary rocks including Devonian limestones, primarily light massive, locally banded, from the most significant relief-forming formation [45] (Vinogradov et al., 1962). Both rock walls, northern and southern, are built of this formation. This is the source area of the rock material for the nival deposits, therefore, these formations are practically homogeneous from the formation composition point of view. The outcrop of subnival sediments is on the edge of the terrace in the landslide niche. The outcrop and slope exposures are to the SE.

Nival deposits described in this paper are from the past, and there are no data yet for any conclusion about their age. The age of the nival deposits is a very interesting problem, to be researched in the future. The only information we have now, is that nival deposits are younger than the two highest terrace levels but older than the rockfalls. It suggests that nival deposits could be either late-glacial or Little Ice Age origin. There are no permanent snow beds at these heights in the Fann Mountains nowadays.

\section{Materials and Methods}

The research had the nature of a reconnaissance survey. Detailed geomorphological mapping of a five-kilometer section of the Saraytag valley was carried out. In the course of the mapping, particular attention was paid to the sequence of sediments, their position, as well as their fractional structure and composition. The heights of fluvial terraces, nival forms, and slope profiles were measured based on field observations and measurements by means of a hand-held GPS receiver.

The locations of the measurement points were recorded using a handheld Garmin $64 \mathrm{~s}$ device set to the GPS and GLONASS reading mode. Each measurement was taken by recording a few waypoints in the immediate neighborhood, and then the height values from those measurements were averaged. The trial pits were photographed in detail and the geolocation of the photographs taken was recorded. 
The digital elevation model (DEM) was also used in spatial analyses. A DEM of $30 \mathrm{~m}$ resolution was acquired from open-source NASA data from the Shuttle Radar Topography Mission (SRTM). According to this model, hillshade processing was carried out at four typical angles $(45,135,225$, and 315), as well as the preparation of slope, roughness, and curvature maps. Arc Pro and QGIS software were used to perform the analysis. Images available in the Google Earth Pro software, which feature higher resolutions than the SRTM data, were used in the analysis.

The photographic documentation of the research outcrop was conducted and basic measurements such as depth of nival origin and subnival origin sediments were realized. The general structure of sediments was documented with traditional on-site macroscopic identification of sediment features (its texture and structure) using the method proposed by Mysielska-Dowigałło [46] because we were unable to transport any probes to the laboratory. The lithological features of the sediments were determined using Miall's lithofacies code [47] including its later modifications [48]. In addition, a $1.5 \mathrm{~m}$ deep outcrop of subnival sediment floor has been made by authors under the "bottle neck", because this part was covered by loose eluvial material.

\section{Results}

The landform of nival deposits has the shape of an irregular, semicircular lobe. Within it, there is a distinguishable culmination in the form of an arch-shaped ridge, bent outwards from the slope. The profile is asymmetrical, with the distal slope being longer and of lower inclination from the internal slope. Additionally, there is a layer of rock blocks of rockfall origin deposited on the nival sediments. The blocks are sharp-edged, not rounded, with the largest ones reaching about $12 \mathrm{~m}$ in diameter. The width of the form as a whole, composed of nival and rockfall sediments, is about $500 \mathrm{~m}$, and the length is about $300 \mathrm{~m}$. In the part adjacent to the slope, there is a $101 \times 34 \mathrm{~m}$ outlet-free depression. In the bottom of the depression, there are sediments of fluvial terrace "20", without any type of nival or rockfall overburden. The block sediments surrounding the outlet-free hollow are 12 meters thick.

The composition of the nival deposits resembles that of a moraine. It is made of unsorted sand-silt material with unrounded stones having a diameter of 5-30 cm. The gravel/boulder part varies depending on the location, ranging from $10 \%$ to $50 \%$ of the landform volume. There are slightly rounded boulders having a diameter of $1-3 \mathrm{~m}$ within the formation. No stratification was found. The complete absence of erratics and any foreign material confirms the local origin of the formation. The thickness of the formation varies significantly, from 0.5 to $12 \mathrm{~m}$.

At the south-eastern edge of the formation, there is a landslide scarp that reveals the sediment profile (Figure 3). The landslide occurred at the edge of the terrace, as well as on the verge of the area where nival deposits are present. The discontinuity between the terrace and the nival formations most likely contributed considerably to the landslide, but the main trigger seems to have been the anthropogenic undercutting of the slope as a result of road construction. The exposure of the nival and terrace sediments shows that nival sediments lie directly on fluvial sediments. They have been deposited on the sediments of terraces with the working names " 20 " and " 15 " $\mathrm{m}$ and also cover the edge between these terraces.

The most interesting aspect is the interaction between the nival and fluvial clasts, which provides evidence of the mechanism underlying the action of subnival waters. Horizontal fluvial sediments of terraces change their dip angle to 22 degrees along with their contact with nival deposits (Figures 4 and 5). The thickness of sediment with a modified dip angle is a maximum of $2.1 \mathrm{~m}$, with this layer consisting of pebbles alternating with gravel and gravelly-sandy-loamy sediments. The sediment layers dip towards the stream bed, with sediments of a nival origin lying above. A change in the dip angle of the terrace layers occurs at a location where the thickness of nival sediments increases rapidly from 0.7 to $2.2 \mathrm{~m}$. 


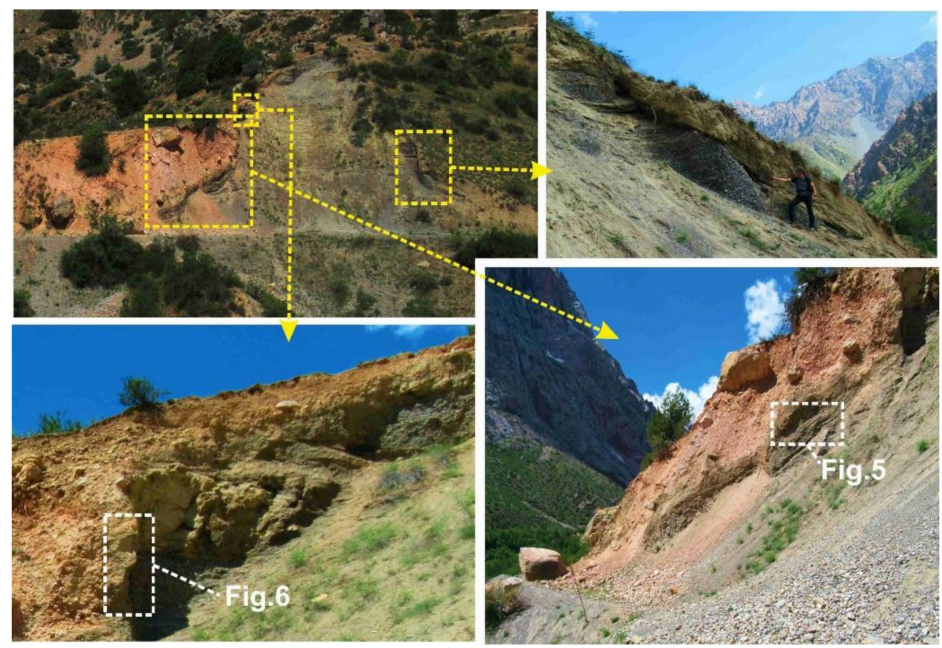

Figure 3. Landslide scarp overview with fluvial and subnival deposits outcrop (photo by P. Dolnicki and P. Kroh).

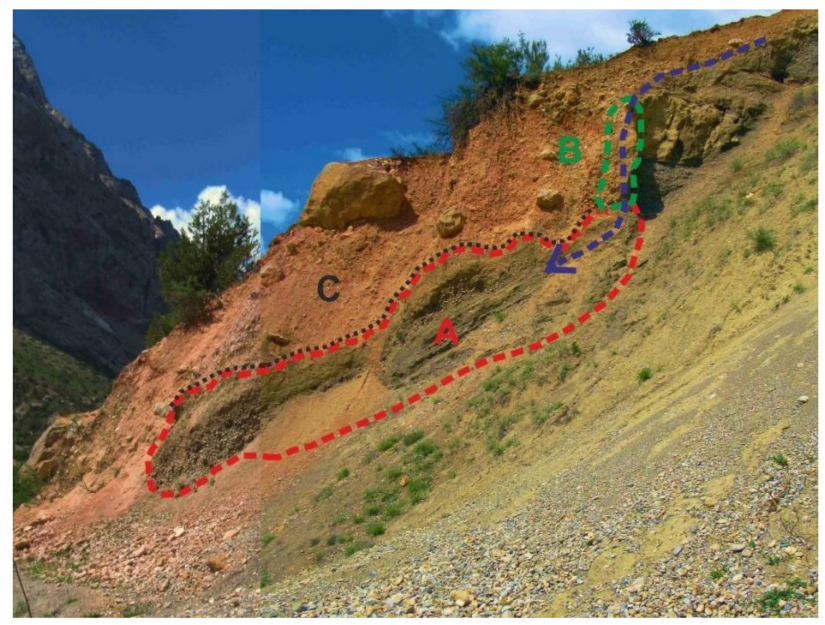

Figure 4. Subnival deposits between nival deposits and fluvial terraces. A, angled subnival sediments; B, "bottle neck"; C, nival deposits. More explanation in the text (photos by P. Dolnicki).

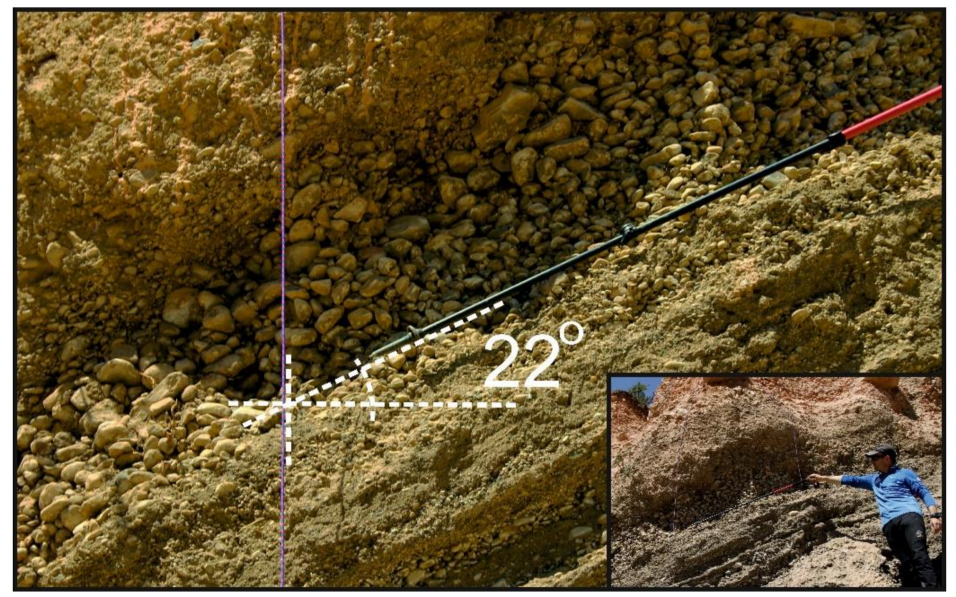

Figure 5. Subnival deposits stratification (photo by P. Dolnicki). 
In place of the increased thickness of nival sediments, there is additional sediment of a "bottle neck" shape sandwiched between the gravels of the terrace and sediments of a nival origin. The sediment is $2.6 \mathrm{~m}$ high and $0.5-0.7 \mathrm{~m}$ wide (Figure 6 ). The border between the nival and subnival sediments (Figure 6, line "a") is clear and almost linear. At its border, the interface between the sediments is direct with no transition zone. The interface between the bottle neck sediments and the fluvial terrace sediments is also pronounced (Figure 6, line " $b$ "). At this margin, there is a blurring of the fluvial sediments, which gradually mix up as they move away from the interface between the layers. In the area closer to border A, the sediments are almost exclusively sandy-clayey sediments, whereas the area adjacent to border $\mathrm{B}$ is predominantly gravel. There are two interlayers in the sediment with a dominance of gravel, i.e., one of them is almost horizontal, with an even floor and a gradual increase in the share of gravel towards the top, while the other is oblique, narrow $(3-6 \mathrm{~cm})$ and clearly distinguishing itself from the adjacent dusty sediment (Figure 6, lines "c"). Poor stratification and gradual transition between gravel and sandy-clayey sediments must be an effect of sedimentation in a strong hydration and partial liquefaction in situ environment, and not flowing water conditions.

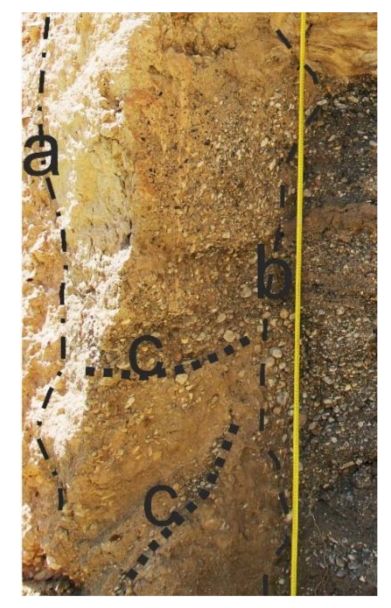

Figure 6. Deposits in the "bottle neck" (photo by P. Kroh).

\section{Discussion}

An outcrop of sediments in a landslide indicates several patterns involved in the formation of the area in question. The example of subnival forms occurs under nival deposits that have been formed as a result of processes associated with large snow patches that have lain there. The position of subnival sediments indicates that the edge of the terrace was shaped before the creation of the nival deposits and subnival sediments. The thickness of nival deposits was greatest where the terrace edge formed before their deposition.

The angled position of layers indicates a depositional environment under the conditions of flowing subnival waters (Figure 4A). Section A of the displaced sediment consists of gravel and stones, as well as a sandy-loamy material. Larger rock clasts are arranged irregularly (Figure 5) and there is no imbrication nor orientation there. Such an arrangement of the layers proves that the material was heavily saturated with water and displaced in a suspended form, and it was not deposited by fast-flowing water, because high energy of water would cause better separation. However, the amount of water causing this process must have been significant, since it enabled such large rock clasts to be displaced.

The edge of the terrace seems to have been a key factor in the shaping of this sediment. The amount of nival material and the shape of pre-nival relief indicate a rapid increase in snow thickness at the edge of a palaeo terrace. This probably also caused an increase in the number of subnival waters. The bigger slope of the terrain under the snow patch must have caused a large increase in the energy of the subnival waters. 
The relief under the snow patch also resulted in the creation of a void between the snow patch and the fluvial terrace base (Figure 4A), which enabled material to be displaced. The preservation of fine grains and the deposition of sandy-clay sediments (Figure 5) indicate a blocked outflow. Otherwise, silts and sands would have been removed by the water. Such specific conditions suggest that the void between the base surface and the snow patch with blocked outflow was only local.

The ceiling of the oblique strata, marked with the black line between deposits A and C (Figure 4), is uneven. Such a shape of subnival sediments and the nival deposits prove that subnival waters have been subjected to hydrostatic pressure, which means that they have filled the entire space between the snow and the ground. To generate hydrostatic pressure in this place, there had to be enough water to completely fill in the space between the snow and the ground. These traces provide evidence of a cycle of gradual melting and filling of the void underneath the snow in section A. The size of section A is much bigger than the size of the bottle neck and it would be impossible for the water flowing through the bottle neck (Figure $4 \mathrm{~B}$ ) to have been under hydrostatic pressure in the void that would encompass the entire section $\mathrm{A}$, which is proven by the stratification of sediments in section $\mathrm{A}$. The origins can also be explained by multi-seasonal and repeated uneven freezing and thawing of the interface between the snow and the ground. In such a situation, the subnival water has a temperature close to $0^{\circ} \mathrm{C}$, and while flowing down, erodes the partially frozen rocks. Such a phenomenon has been observed by Spitzbergen [49]. It could also be the case that both phenomena co-existed, i.e., erosion was amplified by the turbulent flow of water under hydrostatic pressure. The existence of hydrostatic flow is indicated by the regular shapes of the interface between the sediments just below the bottle neck. They appear to be similar in shape to eddy holes found in caves [50-52], but such formations have also been found to be an effect of subglacial waters [53].

The bottle neck deposits (Figure 4B, 6) have been produced by a different mechanism. The filling of the entire bottle neck with mixed gravel, sandy, and clayey sediments with poor stratification and gradual transitions suggest that this sediment was created with no participation of flowing water. The present-day structure of the sediment is clearly indicative of strong hydration of the rock material and its partial liquefaction in situ, without transport. The bottle neck has been filled with sediment in two or three stages. The existence of at least two sequences is evidenced by a clear interlayer of gravels (Figure 6, lines " $c$ ") that have been deposited on the bottom of the hydrated rock material.

The entire sediment has built up in several stages (Figure 7). The stratification of the sediments indicates that the sediment has formed gradually in cycles, i.e., melting out of a void underneath the snow patch and the void filling up with sediment (Figure 7 , phases 1-4). Further research is needed to determine the number of such cycles. If the empty space between the snow patch and the bedrock was created and filled in a single cycle, the oblique sediments would be mixed. Their clear stratification, as well as the extant arrangement of the sediment in the same sequence, clay-sand-gravel, similar to in the adherent terrace layers, indicates that each clast has been formed as a result of a different melt-filling cycle. During the last cycle of melting and filling in section A (as in Figure 4) subnival waters were under hydrostatical pressure (phase 5, 6, and 7). Once section A of the hollow had been filled, the outflow of subnival water was blocked (Figure 7, phase 7), which led to the filling of the bottle neck with deposits, during two or three events (Figure 7 , phase 8). The last stage of the formation of the sediment involved the melting of the whole snow patch and the formation of post-nival sediments (Figure 7, phase 9).

The general description of the sediment structure provided above, with the use of macroscopic field methods, should be improved by laboratory analysis. Although we could not transport the probes into the laboratory during this reconnaissance research, it is planned in the future. After laboratory granulometric-sedimentological analysis, detailed typological differentiation of each layer and levels of sediments should be done. In this paper, general novel information about subnival sedimentation mechanism were 
provided; however, laboratory results would give more data about sedimentation phases, mechanisms, as well as subnival water energy.

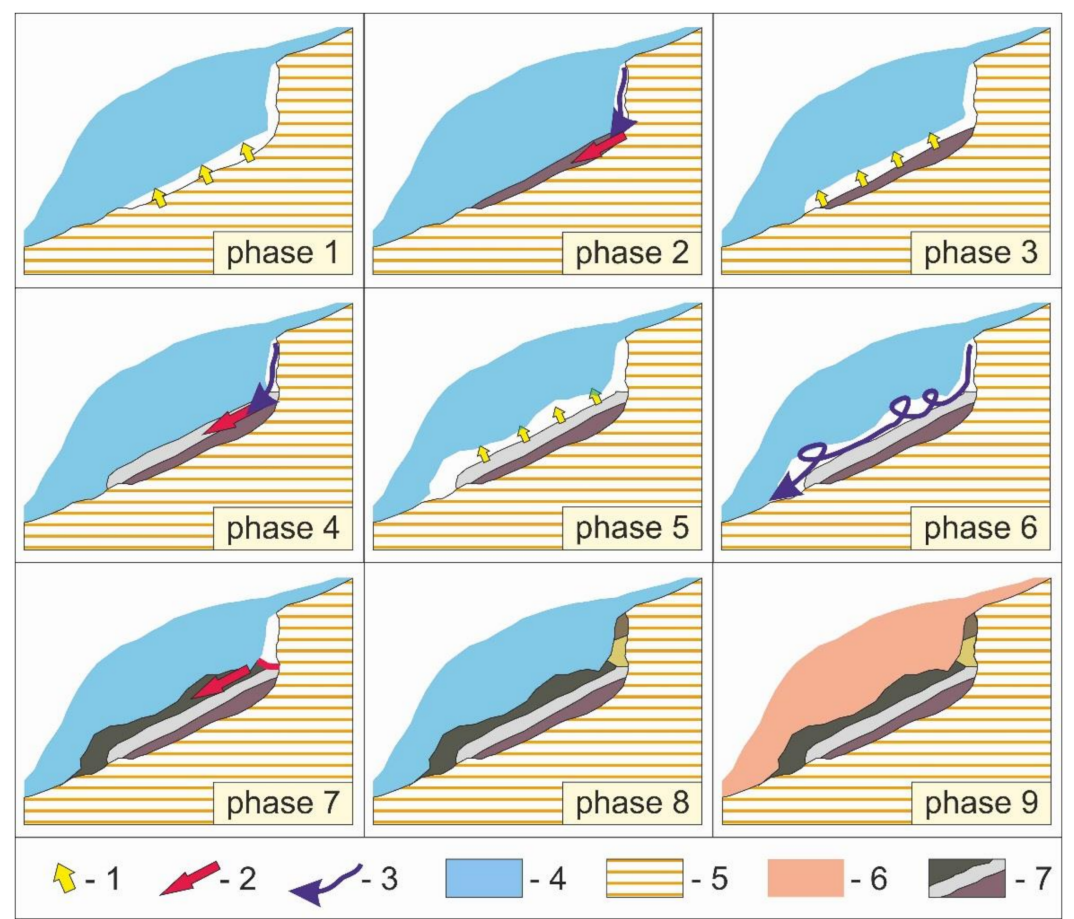

Figure 7. Mechanisms and phases of subnival sediments orgin. Symbols on the shema: 1, melting; 2 , filling in with sediments; 3 , subnival waterflow; 4 , snow patch; 5 , fluvial terraces; 6 , nival deposits; 7 , subnival sediments.

\section{Conclusions}

Sediments in the landslide scarp indicate active operation of subnival waters. They confirm that subnival waters are capable of displacing rock material. Subnival sedimentation can be caused by different mechanisms, i.e., with flowing water, as well as hydration and liquidation of material from the fluvial terrace. In the study site, the energy of subnival waters increased rapidly due to the surface relief under the snow patch, and the deposition of the material was only possible within an empty space created between the snow and the fluvial terrace.

The sediment in question was deposited just below the edge of the terrace, which seems to be crucial for its deposition. An important finding is the evidence that the topography under the snow patch is one of the key factors in subnival processes.

Symptoms of subnival water processes occurred at the edge of the former snow patch. This may prove the assertion formulated in glaciology and geomorphology textbooks that the marginal zones of snow patches are their most morphogenetically active parts. The finding of exclusively local evidence of subnival processes also implies that the impact of even a very large snow patch on subnival sediments does not have to be great. This suggests a prevalence of accumulation over erosional processes within semi-permanent snow beds.

Author Contributions: Conceptualization: P.K.; methodology: P.K., P.D. and A.t.; investigation: P.K., P.D. and A.E; resources: P.K.; writing—original draft preparation: P.K.; writing—review and editing: P.K.; funding acquisition: A.Ł. All authors have read and agreed to the published version of the manuscript.

Funding: This research was funded by internal projects of the Pedagogical University of Krakow, projects numbers: BS-217/G/2019 and WPBU/2020/05/00317. 
Institutional Review Board Statement: Not applicable.

Informed Consent Statement: Not applicable.

Data Availability Statement: The data presented in this study are available on request from the corresponding author.

Acknowledgments: Authors would like to thank Dorota Chmielowska for consulting sedimentological doubts, and Reviewers for their constructive comments.

Conflicts of Interest: The authors declare no conflict of interest.

\section{References}

1. Matthews, J.A.; Wilson, P.; Mourne, R.W. Landform transitions from pronival ramparts to moraines and rock glaciers: A case study from the Smørbotn cirque, Romsdalsalpane, southern Norway. Geogr. Ann. Ser. A Phys. Geogr. 2017, 99, 15-37. [CrossRef]

2. Triglav-Čekada, M.; Barborič, B.; Ferk, M.; Zorn, M. Nationwide aerial laser scanning reveals relict rock glaciers and protalus ramparts in Slovenia. Cryosphere Discuss. 2017, 10, 1-17.

3. Scapozza, C. Investigation on protalus ramparts in the Swiss Alps. Geogr. Helv. 2015, 70, 135-139. [CrossRef]

4. Brook, M.S.; Williams, J. A Relict Pronival (Protalus) Rampart in the Tararua Range, North Island, New Zealand. Permafr. Periglac. Process. 2013, 24, 67-74. [CrossRef]

5. Lindner, L.; Marks, L. Types of debris slope accumulations and rock glaciers in South Spitsbergen. Boreas 2008, 14, 139-153. [CrossRef]

6. Rapp, A.; Nyberg, R. Mass movements, nivation processes and climatic fluctuations in northern Scandinavian mountains. Nor. Geogr. Tidsskr. Nor. J. Geogr. 1988, 42, 245-253. [CrossRef]

7. Gordon, L.S.; Ballantyne, C.K. 'Protalus ramparts' on Navajo Mountain, Utah, USA: Reinterpretation as blockslope-sourced rock glaciers. Permafr. Periglac. Process. 2006, 17, 179-187. [CrossRef]

8. Castaldini, D.; Coratza, P.; Panizza, M. Landslides or moraines? A new geomorphological map of the area of Mt. Cimone (the highest peak of the Northern Apennines, Italy). In Landslide Processes: From Geomorphologic Mapping to Dynamic Modeling; CERG Editions: Strasbourg, France, 2009; pp. 9-14.

9. Colucci, R.; Boccali, C.; Žebre, M.; Guglielmin, M. Rock glaciers, protalus ramparts and pronival ramparts in the south-eastern Alps. Geomorphology 2016, 269, 112-121. [CrossRef]

10. Ballantyne, C.K. Periglacial Geomorphology; John Wiley \& Sons: Hoboken, NJ, USA, 2018.

11. Cañadas, E.S.; López-Moreno, J.I.; Gómez-Lende, M.; Pisabarro, A.; Martín-Moreno, R.; Rico, I.; Alonso-González, E. Frozen ground and periglacial processes relationship in temperate high mountains: A case study at Monte Perdido-Tucarroya area (The Pyrenees, Spain). J. Mt. Sci. 2020, 17, 1013-1031. [CrossRef]

12. Pisabarro, A. Snow cover as a morphogenic agent determining ground climate, landforms and runoff in the Valdecebollas massif, Cantabrian Mountains. Cuad. Investig. Geográfica 2020, 46, 81-102. [CrossRef]

13. Nelson, F.E. Cryoplanation terraces: Periglacial cirque analogs. Geogr. Ann. Ser. A Phys. Geogr. 1989, 71, 31-41. [CrossRef]

14. Hughes, P.; Gibbard, P.L.; Woodward, J.C. Relict rock glaciers as indicators of Mediterranean palaeoclimate during the Last Glacial Maximum (Late Würmian) in northwest Greece. J. Quat. Sci. 2003, 18, 431-440. [CrossRef]

15. Evans, I.S. Glaciers, rock avalanches and the 'buzzsaw'in cirque development: Why mountain cirques are of mainly glacial origin. Earth Surf. Process. Landf. 2020. [CrossRef]

16. Hughes, P.; Fletcher, W.J.; Bell, B.A.; Braithwaite, R.J.; Cornelissen, H.L.; Fink, D.; Rhoujjati, A. Late Pleistocene glaciers to present-day snowpatches: A review and research recommendations for the Marrakech High Atlas. Mediterr. Geosci. Rev. 2020, 2, 163-184. [CrossRef]

17. Hedding, D.W. Pronival ramparts: Origin and development of terminology. Erdkunde 2016, 70, 141-151. [CrossRef]

18. Shakesby, R.A. Pronival (protalus) ramparts: A review of forms, processes, diagnostic criteria and palaeoenvironmental implications. Prog. Phys. Geogr. 1997, 21, 394-418. [CrossRef]

19. Hedding, D.W.; Sumner, P.D. Diagnostic criteria for pronival ramparts: Site, morphological and sedimentological charac-teristics. Geogr. Ann. Ser. A Phys. Geogr. 2013, 95, 315-322. [CrossRef]

20. Hedding, D.W. Pronival ramparts: A review. Prog. Phys. Geogr. 2016, 40, 835-855. [CrossRef]

21. Margold, M.; Treml, V.; Petr, L.; Nyplová, P. Snowpatch hollows and pronival ramparts in the krkonoše mountains, czech republic: Distribution, morphology and chronology of formation. Geogr. Ann. Ser. A Phys. Geogr. 2011, 93, 137-150. [CrossRef]

22. Scotti, R.; Brardinoni, F.; Alberti, S.; Frattini, P.; Crosta, G.B. A regional inventory of rock glaciers and protalus ramparts in the central Italian Alps. Geomorphology 2013, 186, 136-149. [CrossRef]

23. Lewis, W.V. Snow-Patch Erosion in Iceland. Geogr. J. 1939, 94, 153. [CrossRef]

24. Raczkowska, Z. Nivation in the high Tatras, Poland. Geogr. Ann. Ser. A Phys. Geogr. 1995, 77, 251-258. [CrossRef]

25. Christiansen, H.H. Effects of nivation on periglacial landscape evolution in western Jutland, Denmark. Permafr. Periglac. Process. 1996, 7, 111-138. [CrossRef]

26. Kariya, Y. Holocene landscape evolution of a nivation hollow on Gassan volcano, northern Japan. Catena 2005, 62, 57-76. [CrossRef] 
27. Kroh, P. Characteristics of environmental relaxation in mountain landscapes following natural disturbances, the tatra mountains, Poland. In Proceedings of the 13th SGEM GeoConference on Ecology, Economics, Education and Legislation, Sofia, Bulgaria, 16-22 June 2013; SGEM: Sofia, Bulgaria, 2013; Volume 1, p. 185. [CrossRef]

28. Kroh, P. Relaxation Phases Following the Mountain Landscape Disturbance, the Tatra Mts, Poland. In Proceedings of the 13th SGEM GeoConference on Ecology, Economics, Education and Legislation, Sofia, Bulgaria, 16-22 June 2013; SGEM: Sofia, Bulgaria, 2013; Volume 1, p. 805. [CrossRef]

29. Paquette, M.; Fortier, D.; Lafrenière, M.; Vincent, W.F. Periglacial slopewash dominated by solute transfers and subsurface erosion on a High Arctic slope. Permafr. Periglac. Process. 2020. [CrossRef]

30. Kirkbride, M.P. A Snow-Push Mechanism for Ridge Formation in the Cairngorm Mountains, Scotland. Scott. Geogr. J. 2015, 132, 66-73. [CrossRef]

31. Christiansen, H.H. Nivation forms and processes in unconsolidated sediments, NE Greenland. Earth Surface Processes and Landforms. J. Br. Geomorphol. Group 1998, 23, 751-760.

32. Pissart, A.; Francou, B. Vertical movements of boulders in a subnival boulder pavement at $2800 \mathrm{~m}$ a.s.l. in the Alps (France). Permafr. Periglac. Process. 1992, 3, 203-208. [CrossRef]

33. Shakesby, R.A.; Matthews, J.A.; McCarroll, D. Pronival ("Protalus") Ramparts in the Romsdalsalpane, Southern Norway: Forms, Terms, Subnival Processes, and Alternative Mechanisms of Formation. Arct. Alp. Res. 1995, 27, 271. [CrossRef]

34. Thorn, C.E.; Hall, K. Nivation and cryoplanation: The case for scrutiny and integration. Prog. Phys. Geogr. Earth Environ. 2002, 26, 533-550. [CrossRef]

35. Wu, T.; Sang, S.; Wang, S.; Yang, Y.; Li, M. Remote sensing assessment and spatiotemporal variations analysis of ecological carrying capacity in the Aral Sea Basin. Sci. Total. Environ. 2020, 735, 139562. [CrossRef] [PubMed]

36. $\mathrm{Wu}, \mathrm{H} . ; \mathrm{Wu}, \mathrm{J} . ; \mathrm{Li}, \mathrm{J} . ; \mathrm{Fu}, \mathrm{C}$. Spatial variations of hydrochemistry and stable isotopes in mountainous river water from the Central Asian headwaters of the Tajikistan Pamirs. Catena 2020, 193, 104639. [CrossRef]

37. Rahmonov, O.; Szczypek, T.; Niedźwiedź, T.; Myga-Piątek, U.; Rahmonov, M.; Snytko, V.A. The human impact on the transformation of juniper forest landscape in the western part of the Pamir-Alay range (Tajikistan). Environ. Earth Sci. 2017, 76, 324. [CrossRef]

38. Owczarek, P.; Opała-Owczarek, M.; Rahmonov, O.; Mendecki, M.J. 100 Years of earthquakes in the Pamir region as recorded in juniper wood: A case study of Tajikistan. J. Asian Earth Sci. 2017, 138, 173-185. [CrossRef]

39. Williams, M.W.; Konovalov, V.G. Central Asia Temperature and Precipitation Data, 1879-2003, Version 1. NSIDC: National Snow and Ice Data Center: Boulder, CO, USA. 2008. Available online: https://nsidc.org/data/G02174/versions/1 (accessed on 11 October 2019).

40. Seim, A.; Omurova, G.T.; Azisov, E.; Musuraliev, K.; Aliev, K.; Tulyaganov, T.; Nikolyai, L.; Botman, E.; Helle, G.; Liñán, I.D.; et al. Climate Change Increases Drought Stress of Juniper Trees in the Mountains of Central Asia. PLoS ONE 2016, 11, e0153888. [CrossRef]

41. Bolch, T. Climate change and glacier retreat in northern Tien Shan (Kazakhstan/Kyrgyzstan) using remote sensing data. Glob. Planet. Chang. 2007, 56, 1-12. [CrossRef]

42. Zech, R.; Röhringer, I.; Sosin, P.; Kabgov, H.; Merchel, S.; Akhmadaliev, S.; Zech, W. Late Pleistocene glaciations in the Gissar Range, Tajikistan, based on 10Be surface exposure dating. Palaeogeogr. Palaeoclim. Palaeoecol. 2013, 369, 253-261. [CrossRef]

43. Stanturf, J.A.; Botman, E.; Kalachev, A.; Borissova, Y.; Kleine, M.; Rajapbaev, M.; Chyngozhoev, N.; Nyam-Osor, B. Dryland Forest Restoration Under a Changing Climate in Central Asia and Mongolia. Mong. J. Biol. Sci. 2020, 18, 3-18. [CrossRef]

44. Shchegoleva, N.V.; Turginov, O.T.; Zhabborov, A.M.; Kodirov, U.K. Ecological and Geographical Features of the Western Pamir-Alai endemic Ranunculus Botschantzevii Ovcz; Bulletin of Tomsk State University. Biology: Tomsk, Russia, 2020; p. 49. (in Russian)

45. Vinogradov, P.D.; Menakov, A.I.; Ovcinnkov, S.K.; Tarasenko, A.T. Map of Bedrock Geology of Commonwealth of Independent States, scale 1:200 000, map J-42-IX, VSEGEI. 1962. Available online: http:/ / webmapget.vsegei.ru/index.html (accessed on 3 December 2020).

46. Mycielska-Dowgiałło, E. Research methods for textural features of clastic deposits and the significance of interpreta-tional results. In Research into the Textural Features of Quaternary Sediments and Some Dating Methods; Mycielska-Dowgiałło, E., Rutkowski, J., Eds.; The Family Alliance School of Higher Education Press: Warsaw, Poland, 2007; pp. 95-181. (In Polish)

47. Miall, A.D. A review of the braided-river depositional environment. Earth Sci. Rev. 1977, 13, 1-62. [CrossRef]

48. Zieliński, T.; Pisarska-Jamroży, M. Which features of deposits should be included in a code and which not? Prz. Geol. 2012, 60, 387-397, (in Polish with English summary).

49. Czeppe, Z. Roczny Przebieg Mrozowych Ruchów Gruntu w Hornsundzie (Spitsbergen) 1957-1958 (Annual Course of Frost Ground Movements at Hornsund) Spitsbergen (1957-1958); Zeszyty Naukowe Uniwersytetu Jagiellonskiego: Kraków, Poland, 1961; Volume 42, p. 74. (in Polish)

50. Jennings, J.N. Karst. Australian National University Press: Canberra, Australia, 1971; p. 252. Available online: http: / / openresearch-repository.anu.edu.au.

51. Calaforra, J.M.; De Waele, J. New peculiar cave ceiling forms from Carlsbad Caverns (New Mexico, USA): The zenithal ceiling tube-holes. Geomorphology 2011, 134, 43-48. [CrossRef]

52. Gallay, M.; Hochmuth, Z.; Kaňuk, J.; Hofierka, J. Geomorphometric analysis of cave ceiling channels mapped with 3-D ter-restrial laser scanning. Hydrol. Earth Syst. Sci. 2016, 20, 1827. [CrossRef]

53. Higgins, C. Origin of Potholes in Glaciated Regions. J. Glaciol. 1957, 3, 11-12. [CrossRef] 